\title{
VEGETABLE CULTIVATION IN LIMITED LAND USING HYDROPONIC SYSTEM
}

\author{
Mochammad Mukti Ali \\ Universitas Mercu Buana Jakarta, Indonesia.
}

\begin{abstract}
This training is an activity related to the economic empowerment of the community through the development of limited cultivation of vegetable crops using a hydroponic system. Counseling and Training on the use of hydroponic farming methods through residents of Anggadita villages will help them know how to grow vegetables by using the system to improve community welfare. For this reason, training activity will assist in the cultivation of vegetables using the system and will be able to become an example in the cultivation of hydroponic vegetable plants. Apart from being beneficial for themselves, this behavior will at least help reduce the economic burden of the family, especially for the fulfillment of healthy vegetables by utilizing the limited land. The expected output can be realized from this activity is the development of knowledge on how to grow hydroponics in the residents of the Anggadita villages, the formation of a social care group hydroponics in the Mitra village that can increase the awareness of the community members in the cultivation of hydroponic plants.
\end{abstract}

Keywords: Limited Land, Hydroponics System, Economic Increasing, Social Groups

\section{INTRODUCTION}

The yard is a plot of land that is located directly around the house, mostly fenced and has clear boundaries, planted with one or various types of plants, which are used for daily needs or traded. The yard is a potential land to be developed into productive agricultural land, especially to meet nutritious food needs for their owners. The yard can be used to grow various types of plants such as staple food plants, ornamental, medicine, and others. Structuring plants in the yard can be done in various ways. Land limitations are not obstacles to actualizing the potential economic value it has. The land is optimized for growing high economic value plants such as food plants, ornamental plants, medicinal plants and oxygen-supplying plants in large quantities.

Urban areas that are far from food production sources are also the reason for the importance of urban agriculture. The freshness of available foods such as vegetables and fruits is degraded in quality when shipping. Planting technology can be done in various ways such as Verticulture (using potted / water pipe media arranged vertically), Polybags, Hydroponics, Aeroponics, Tabulampot, and others. Utilization of the yard by planting vegetables in pots can be fullfill the needs of the owner's household. Besides that also growing vegetables in the yard can preserve the environment because of the oxygen produced by these plants.

Hydroponics is a modern technology in agriculture in cultivation techniques that uses essential nutrients needed by plants to obtain quality products and is free from the use of plant-disturbing organisms originating from the soil. The first hydroponic system developed in Indonesia was the hydroponic substrate, which is a system that uses media other than soil and sterile, such as husk charcoal, sand, sawdust, coconut belts, and others.

The history of the origin of the word Hydroponics comes from the Greek, the word of hydro means water and power. So the meaning of hydroponics is to empower water, and can be interpreted as an agricultural system without using soil media but only using water media that contains nutrients. Hydroponics is plant cultivation without soil and uses a mixture of essential nutrients dissolved in water. The most important requirement for this system is the availability of sufficient water.

Hydroponic plants can grow well if the roots get enough air, water, and nutrients. The characteristics of a good hydroponic growing media must be able to absorb and deliver water, do not affect the $\mathrm{pH}$ water, do not change color, and do not easily rot or decay.

The history of the development of the hydroponic system begins with research relating to nutrient requirements needed by plants. Two scientists, Sach and Knop, managed to show that a plant can live in an Inert Grow Medium

(does not cause chemical reactions) given a nutrient solution. This research shows that solutions containing nitrogen $(\mathrm{N})$, phosphorus $(\mathrm{P})$, potassium $(\mathrm{K})$, sulfur $(\mathrm{S})$, calcium $(\mathrm{Ca})$, and magnesium $(\mathrm{Mg})$ are the elements most needed by plants (macronutrients). Further research shows plants also need elements such as iron (Fe), chlorine $(\mathrm{CI})$, manganese $(\mathrm{Mn})$, boron $(\mathrm{B})$, zinc $(\mathrm{Zn})$, copper $(\mathrm{Cu})$, and molybdenum $(\mathrm{Mo})$ in small amounts ( micronutrients) (Resh 1980). 
Research conducted by Sach and Knop, led to other research began to focus on making a solution that can meet the needs of plant nutrients. Several plant nutrient formulas have been discovered by experts such as Tollens (1882), Tottingham (1914), Shieve (1915), Hoagland (1919), Trelease (1933), Arnon (1938), and Robbins (1946). The plant nutrient formula found is still used in the laboratory until now (Resh 1980).

The use of hydroponic plant cultivation techniques has various advantages. Roberto (2004) states that some of the benefits derived from the use of this technique are counteracting the attack of pests, fungi, and diseases of soil origin so as to avoid the use of pesticides; reduce the use of large planting areas; increase yields and reduce high production costs. Besides that, using a hydroponic system can accelerate the time of harvest, the use of water and nutrients that are measured, and the quality, quantity, and continuity of guaranteed yields (Sudarmodjo 2008).

All profits obtained by using a hydroponic system are largely determined by the content of macro and micronutrients. Cultivating with a hydroponic system will make it easier for farmers to manage the nutrient requirements needed by a plant directly and efficiently. The regulation of crop input needs can directly optimize the genetic potential of cultivated plants and increase yields (Resh 1980, Sudarmodjo 2008).

In Anggadita village, several problems can be resolved by training in vegetable cultivation with the hydroponic system. The problems include; lack of land for agriculture, hygiene of vegetables available in the market, high prices of healthy vegetables that are only available in supermarkets, limited time to do conventional selfcultivation, and lack of awareness to use the yard and knowledge of how to plant with a hydroponic system.

\section{TARGET OUTCOME}

The general target to be achieved through this training activity is to increase the community's knowledge and ability to grow crops using a hydroponic system, which can be done in the yard. Also, to be able to manage to farm with a hydroponic system, it is necessary to know the concepts of the hydroponic system procedures.

There are 6 basic of hydroponics system, which are Wick System, Water Culture System, Ebb, and Flow / Flood and Drain System, Drip Irrigation System, NFT System (Nutrient Film Technique), and Aeroponic Systems.

The Wick System (Figure 1) is the simplest type of hydroponics. This system is a passive system, which means there is no moving system. Nutrient solutions are absorbed by the growing media from the reservoir using an axis (utilizing the capillary power of the axis). This system can use a variety of growing media, including Perlite, Vermiculite, Pro-Mix, and Coconut Fiber.
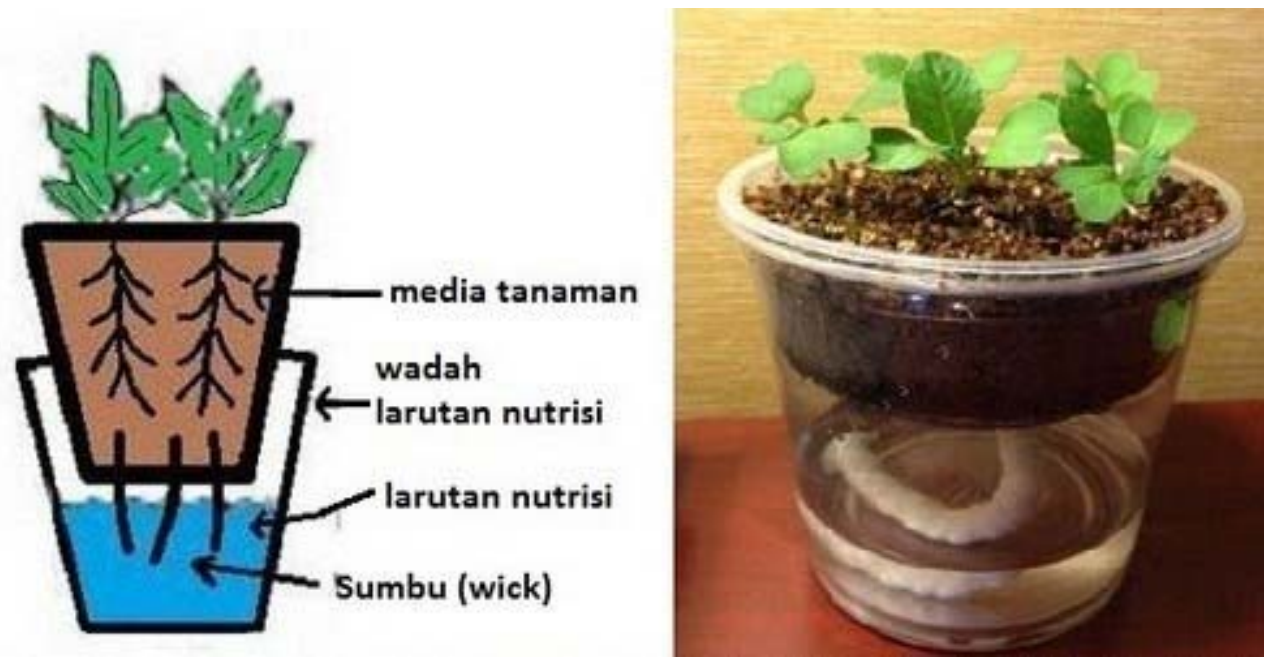

Figure 1. The Wick System

Hydroponic plants can grow well if the root environment gets enough air, water, and nutrients. The characteristics of a good hydroponic growing media must be able to absorb and deliver water, do not affect the $\mathrm{pH}$ of the water, do not change color, and do not easily rot or decay. In this hydroponic system, the most important requirement is the availability of water must be sufficient and maintain adequate nutrition. 
Controlling the concentration of nutrient content is very important to do at all times. The nutrient solution must have a thickness of about $2 \mathrm{mS} / \mathrm{cm}$ where the nutrient content is still maintained. Control can be done by using an EC meter or manually by looking at the state of the fertilizer (the thickness of the solution) and the state of the plant (plants that lack nutrients can be seen from the leaves that begin to show color changes to "slightly yellowish").

The increase in EC solution cannot be too drastic because it greatly affects plant metabolism. The effect is very significant in mature plants. A drastic decrease in EC causes the leaves to become more stiff and difficult to grow due to very low levels of dissolved nutrients. The magnitude of the increase and decrease in EC should be kept to a minimum.

The availability of nutrients for plants is also determined by the degree of acidity of the solution (pH). The degree of acidity shows the level of nutrient absorption by plants. The degree of acidity that is too high can interfere with the absorption of microelements by plants. While a low $\mathrm{pH}$ will also interfere with the absorption of macronutrients such as N, P and K. The degree of acidity suitable for nutrient absorption by plants is 6.3-6.5 (Roberto 2004).

During the planting period, it is very important to take care of plants including controlling organisms of plant pests and plant diseases, maintaining the concentration of nutrients in the water, and the speed of nutrient drainage.

The control of plant pests is done manually without using pesticides or other chemicals. Control is carried out periodically and carried out carefully and regularly so that pests can be quickly identified and well localized before being destroyed.

The resulting outcome is increased knowledge of the surrounding community on the cultivation of hydroponic system plants so that it will increase the desire of the community to cultivate hydroponic plants in the yard of each resident's home in Anggadita village.

\section{METHODOLOGY}

The activity methods used are as follows:

1. Structured, in the form of exposure to material and theory to provide knowledge and understanding of the maintenance of hydroponic system plants.

2. The simulation carries out maintenance according to the theoretical steps.

The method of implementing this training activity is based on Ginanjarsari (2014), hydroponics will not succeed smoothly if it does not carry out some maintenance as follows:

1. Nutrition supply, the higher the TDS number, the more concentrated the concentration of cations and anions and the higher the conductance of electricity. In hydroponics system cultivation, TDS meter plays a very important role, plants can grow well if the ppm given in nutrient solution is adjusted according to plant needs. Nutrition measurements should be done every day so that the nutrition of ppm is monitored. Unstable temperatures also affect ppm size.

2. Pest control, the pest is a plant-disturbing organism, divided into 3 namely pests, weeds, and diseases. Pest groups that often interfere with hydroponic plants are the PESTS and DISEASE groups. Because hydroponics is a technique designed to minimize the growth of weeds, weeds are not a significant problem in the cultivation of plants in a hydroponic system.

3. Replanting is an activity to replace the planting hole where the plants die. It is commonly used in industrialscale hydroponic systems. Replanting begins at the age of the plant 15 days after planting.

4. Nutrition Hose Control, carried out checking 3 times a day. If there is a problem with the hose, this will be very detrimental because one gully (batch) containing the plant will automatically die.

5. Control on PPM and nutrient $\mathrm{pH}$, using a TDS meter and $\mathrm{pH}$ meter. Checking the $\mathrm{pH}$ and PPM of nutrition is recommended to be carried out 3 times at 9 AM, 12 PM and 3 PM. It aims to find out how much changes in the nutrient content that flows through hydroponic plants. If there is an error in the calculation, then the error can be corrected immediately.

6. Irrigation system, hydroponic plant nutrient irrigation that needs to be checked every day is the state of the pump and the reservoir of nutrient water. Usually, if the nutrient water in the reservoir runs out, filling the water should be done immediately so that the plant does not die. 


\section{RESULT}

This activity was held in the context of routine community service activities as one of the Tri Dharma University. This activity was held well and on time following what was expected. The number of participants attended was 15 people.

Training materials were distributed to participants regarding theoretical and practical material. The training material is presented in the form of power points and cases of hydroponic plant cultivation. The training material is explained interactively in the form of presentations and discussions in class and also the introduction of hydroponic plants discussed in groups.

This community service activity is carried out with field surveys, interviews, and hands-on practice. Based on the results of interviews with several residents, they need training in introducing hydroponic plants to increase knowledge and technical skills to obtain the ability to cultivate hydroponic plants. Related to the identification of the problems that have been discussed, the expected problem discussions are as follows:

1. Provide understanding and knowledge of hydroponic system plants to create a prosperous society.

2. Providing training and technical skills to the community regarding hydroponic system plants.

3. Provide a simulation of the introduction of hydroponic plant types.

This activity was evaluated in several ways, with 15 participants. The presentation of training materials is carried out according to the training schedule. From the recapitulation results of the training evaluation sheet, it was found that the participants stated that the training was very useful to improve understanding related to the effectiveness of interpersonal communication in the introduction of hydroponic plants.

The factors that make this activity successful are:

a. Excellent communication between the community service team and participants.

b. Good collaboration between the community service team and participants.

c. Enthusiastic participants participated in the training until the completion of the training.

While the factors that become obstacles are:

a. Training cannot only be carried out in one day because quite a lot of participants do not know the types of pests in hydroponic plant cultivation.

b. Limited funds in implementing the training.

\section{CONCLUSION}

The results of the discussion of the entire set of training activities can be concluded as follows:

a. Overall, the training participants were dominated by individuals who had creative enthusiasm in the plantation business. Participants can express their ideas and opinions, but need time to adjust well during the training and also the mindset of the participants is quite open and flexible.

b. The atmosphere in the training class is quite lively and 'alive'. The participants are creative and tend to express their opinions openly, both during group discussions and individually.

c. The participants said the training activities were interesting, many 'new' things were obtained and learned during the activity. The training material is very useful for participants to better understand about hydroponic plants.

d. This activity can be used as a means of communication, friendship and socialization of the Master of Management Postgraduate Program at Mercu Buana University to the community, as well as embodying the social responsibility of the Higher Education Institution - Tri Dharma University.

From the conclusions above, there need to be continuous improvements to get the expected results by resolving existing obstacles. The advice that needs to be followed up is that the duration of the implementation of training activities can be extended, from one day to two days of training. Within two days of the activity, it is expected that material and practices related to the introduction of hydroponic plants in order to be able to understand suitable plants according to their needs and environmental conditions can be delivered more optimally. 


\section{REFERENCES}

Anonim. 2008. Makalah Pelatihan Aeroponik Sayuran Eksklusif. Momenta Agrikultur. Jakarta., Tidak dipublikasikan.

Ginanjarsari, Rosdiana R. 2014. Budidaya dan Pemasaran Tanaman Selada Keriting Secara NFT (Nutrient Film Technique). Dalam Laporan Hasil Magang Di PT. Momenta Agrikultura "Amazing Farm" Kebun Cikahuripan-2 Lembang, Bandung. 63 Halaman.

Resh H. 1980. Hydroponic Food Production. Newconcept Press. New Jersey.

Roberto K. 2004. How-To Hydroponics Fourth Edition. Futuregarden Press. New York.

Rukmana R. 1994. Bertanam kangkung. Kanisius. Yogyakarta.

Sudarmodjo. 2008. Hidroponik. Parung Farm. Bogor., Tidak dipublikasikan.

Susila A. 2006. Panduan Budidaya Tanaman Sayuran. Departemen Agronomi dan Hortiikultura IPB. Bogor.

Sutiyoso, Yos. 2003. Aeroponik Sayuran Budidaya dengan Sistem Pengabutan. Penebar Swadaya. Jakarta.

Suwandi. 2009. Menakar kebutuhan Hara Tanaman Dalam PengembanganInovasi Budidaya Sayuran Berkelanjutan. Pengembangan Inovasi Pertanian. Bogor.

Ginanjarsari, Rosdiana R. 2014. Budidaya dan Pemasaran Tanaman Selada Keriting Secara NFT (Nutrient Film Technique). Dalam Laporan Hasil Magang Di PT. Momenta Agrikultura "Amazing Farm" Kebun Cikahuripan-2 Lembang, Bandung. 63 Halaman. 